Abstracta Iranica Abstranica

Revue bibliographique pour le domaine irano-aryen

Volume 32-33 | 2013

Comptes rendus des publications de 2009-2010

\title{
Judith A. Lerner. Considerations on an Aspect of Jewish Culture under the Sasanians: The Matter of Jewish
} Sigillography

\section{Rika Gyselen}

\section{(2) OpenEdition \\ 1 Journals}

\section{Édition électronique}

URL : http://journals.openedition.org/abstractairanica/40549

DOI : 10.4000/abstractairanica.40549

ISSN : 1961-960X

Éditeur :

CNRS (UMR 7528 Mondes iraniens et indiens), Éditions de l'IFRI

\section{Édition imprimée}

Date de publication : 1 décembre 2013

ISSN : 0240-8910

Référence électronique

Rika Gyselen, « Judith A. Lerner. Considerations on an Aspect of Jewish Culture under the Sasanians: The Matter of Jewish Sigillography », Abstracta Iranica [En ligne], Volume 32-33 | 2013, document 183, mis en ligne le 01 juillet 2016, consulté le 05 octobre 2020. URL : http://journals.openedition.org/ abstractairanica/40549; DOI : https://doi.org/10.4000/abstractairanica.40549

Ce document a été généré automatiquement le 5 octobre 2020.

Tous droits réservés 


\title{
Judith A. Lerner. Considerations on an Aspect of Jewish Culture under the Sasanians: The Matter of Jewish Sigillography
}

\author{
Rika Gyselen
}

\section{RÉFÉRENCE}

Judith A. Lerner. « Considerations on an Aspect of Jewish Culture under the Sasanians: The Matter of Jewish Sigillography ». Journal of the American Oriental Society 129.4, 2009, p. 653-664.

1 Cet article est un compte rendu très circonstancié de l'ouvrage de D. M. Friedenberg, Sasanian Jewry and ist Culture: A Lexicon of Jewish and Related Seals, Urbana, University of Illinois Press, 2009. Un compte rendu plus succinct de ce même ouvrage a été publié dans St. Ir. 39-1, 2010, p. 146-149.

2 Lerner fait état de la bibliographie incomplète et peu à jour. Elle met en doute la méthode d'investigation de Friedenberg qui essaie d'identifier les noms juifs notés sur des sceaux sassanides à des personnages renommés de la communauté juive, en laissant de côté qu'aussi d'autres juifs, entre autres les marchands, ont fait usage de sceaux. De nombreuses remarques pertinentes et critiques portent sur le chapitre 4 de cet ouvrage qui prétend traiter de " la nature et la fonction des sceaux sassanides », pour conclure qu'à part la publication de quelques rares sceaux inédits, cet ouvrage n'est pas une référence à retenir. 


\section{AUTEURS}

\section{RIKA GYSELEN}

CNRS/Mondes iranien et indien, Paris 